\title{
Idiopathic achalasia
}

INSERM

\section{Source}

INSERM. (1999). Orphanet: an online rare disease and orphan drug data base. Idiopathic achalasia. ORPHA:930

Idiopathic achalasia (IA) is a primary esophageal motor disorder characterized by loss of esophageal peristalsis and insufficient lower esophageal sphincter (LES) relaxation in response to deglutition. 